\title{
Review:
}

\section{Phytochemistry and Pharmacology of Munronia Genus (Meliaceae)}

\author{
Kindi Farabi ${ }^{1}$ and Unang Supratman ${ }^{1,2^{\star}}$ \\ ${ }^{1}$ Department of Chemistry, Faculty of Mathematics and Natural Sciences, Universitas Padjadjaran, \\ Jl. Raya Bandung-Sumedang Km. 21, Jatinangor, Sumedang 45363, Indonesia \\ ${ }^{2}$ Central Laboratory, Universitas Padjadjaran, Jl. Raya Bandung-Sumedang Km. 21, \\ Jatinangor, Sumedang 45363, Indonesia
}

${ }^{*}$ Corresponding author:

tel: $+62-22-7794391$

email: unang.supratman@unpad.ac.id

Received: March 5, 2021

Accepted: June 10, 2021

DOI: $10.22146 /$ ijc. 64502

\begin{abstract}
Munronia is a genus in the Meliaceae family, which consists of over 17 species that are distributed in the subtropical and tropical area of Asia, including southern China, Vietnam, Myanmar, Sri Lanka, India, Indonesia, and the Philippines. It is known that these plants contain valuable bioactive compounds. Since the first isolation of new stigmastane steroid was reported in 2003, researchers have been able to study the chemical composition of these plants, especially the largest secondary metabolite obtained, limonoid. About 97 compounds were isolated successfully and characterized. The reported compounds showed various biological activities, such as antifeedant, antimicrobial, antiangiogenic, cytotoxic against several cancer cell lines, inducing apoptosis, and anti-tobacco mosaic virus activities. Therefore, the results suggest that the use of this plant as a source of bioactive compounds is promising for the medicinal chemistry field.
\end{abstract}

Keywords: biological activity; limonoid; Meliaceae; Munronia; phytochemistry

\section{- INTRODUCTION}

Meliaceae is a family of woody plant which is grown in tropical and subtropical regions. This family consists of approximately 50 genera covering 1,400 species [1]. Meliaceae is well known as a source of diverse natural compounds with interesting biological activity. Some compounds including sesquiterpenoids [2-7], triterpenoids [8-18], diterpenoids [19-21], steroids [2225], limonoids [26-27], alkaloids [28-29], lignan [30-32], flavaglines [33-35], and flavonoids [36-37] have been successively extracted from this family. Those isolated compounds showed interesting biological activities including cytotoxic [38-41], insecticidal [42-43], antimycobacterial [6], antifungal [44-45], antiinflammatory [9,46-47], and antiviral [48]. The high diversity of compounds together with its interesting bioactivity showed that Meliaceae family is a promising source for bioactive compounds for drug development in future.
Munronia is a genus that belongs to the family of Meliaceae, which consists of over 17 species [49] that are distributed in southern China, Vietnam, Myanmar, Sri Lanka, India, Indonesia, and the Philippines [50-51]. Some species of this genus are considered to be endemic. M. yinggelinensis is discovered in Hainan province, China [49] while $M$. delavayi is a vulnerable perennial species that is endemic in the dry-hot valley of the middle/lower Jinsha River [52]. Other rare species of this genus including $M$. pinnata, are a valuable medicinal plant in Sri Lanka [53]. This species is one of the most expensive plant material (US\$ 50-110/kg) used in traditional medicine [54]. Plants of this genus have been known in folk medicine since historical times. In Sri Lanka, the powders of this plant are used to treat malaria, dysentery, fever, skin diseases, and blood cleansing from poisonous snake bites, as well as to prevent hiccups, vomiting, and sore throats [55-56].

To rationalize the link between the valuable 
medicinal uses of this plant and its chemical compositions, researchers are putting effort to explore these plants. The first chemical composition of this plant described is the isolation of a new sterol containing an octadecenoyl, including other compounds such as glycosides and sesquiterpenoids, from $M$. henryi [57]. After that, dozens of new compounds, including limonoids, tirucallane-type triterpenoids, phytosterols, diterpenoids, and glycosides have been successfully isolated mostly from the whole plant and aerial parts of this plants. Furthermore, these isolated metabolites showed extensive biological activity such as insect antifeedant, antifungal, antiangiogenic, anti-tobacco mosaic virus, and anticancer activity. Although research on the exploration of new metabolites from genus Munronia is still going on, to the best of our knowledge, there is no reported review discussed on the phytochemical and biological activity of this genus. This review is expected to provide guidance on the major chemical constituent and biological activity of genus Munronia.

\section{- BOTANY}

Munronia is a genus of the Meliaceae family that consists of over 17 species that are mainly distributed in the tropics and subtropics of Asia [50]. The plants from this genus has unbranched shrublets or sparsely branched with $10-50 \mathrm{~cm}$ in length. Simple odd-pinnate leaves, crenate to serrate, with petiole $1.5-4.0 \mathrm{~cm}$. The stems are usually not braced, glabrous or apical, and covered with appressed puberulence. In general, it has white hermaphrodite flowers. The fruit contains 5 valved loculicidal capsule, each locule contains 1 or 2 seeds with yellowish gray color [58].

\section{- PHYTOCHEMISTRY}

\section{Overview on Isolated Compounds from Munronia Genus}

The first report that the Munronia compound was isolated began in 2003 with the isolation of a new steroid stigmastane with an octadecenoyl substituent. Then, about 97 compounds have been identified from this genus, which includes steroid, terpenoid, limonoid, and other metabolites. Out of all the isolated compounds, limonoid compounds were the largest isolated metabolites from this genus.

\section{Steroid}

There were two classes of steroid compounds isolated from whole plant parts of certain species of the genus Munronia, such as pregane and stigmastane-type steroid. Qi et al. [57] reported a new compound, sitosterol-3-O-12',13'-epoxy-9'-oxo-(10'E)-octadeceno-

ate (1) with the pregnane-type steroid $2 \beta, 3 \beta, 4 \beta$ trihydroxypregnan-16-one (2) from $M$. henryi. From $M$. delavayi, Cai et al. [59] isolated one pregnane-type steroid, $2 \alpha, 3 \alpha, 15 \beta$-trihydroxy-20(S)-tigloyl-pregnane (3) and five stigmastane steroids, i.e. $\beta$-daucosterol (4), 6-hydroxystigmast-4-en-3-one (5), sitoindoside I (6), sitoindoside II (7), $\beta$-sitosterol (8), which come from the same sitosterol core with C-3 modified substituent were obtained. Furthermore, Yan et al. [50] reported pregnane-type steroid, such as munronin S (9) bearing tygloyl oxy unit at C-12 [50]. The chemical structures and source of isolated steroids of the genus Munronia are shown in Fig. 1 and Table 1, respectively.

\section{Terpenoid}

A total of 10 terpenoid compounds, divided into sesquiterpenoid, diterpenoid, and triterpenoids were identified and characterized in genus Munronia. Qi et al. [51] obtained 4a,7 $\alpha$-aromadendranediol (10), an aromadendrene-type sesquiterpenoid from $M$. henryi. Meanwhile, $M$. delavayi gave a simple diterpenoid compound, geranylgeraniol (11) isolated by Cai et al. [60] from the whole plant of this species. Furthermore, Yan et al. [61] reported the isolation and structural determination of a new diterpenoid, munronin $\mathrm{R}$ (12) from $M$. henryi. Another type of terpenoid compounds reported in genus Munronia was triterpenoid compounds. All triterpenoid compounds isolated from this genus possessed a tirucallane-type triterpenoid. From ethanolic extract of whole plants M. delavayi, Cai et al. [60] reported seven tirucallane-type triterpenoids, i.e. sapelin A (13), munronosides I-IV (14-17), melianodiol (18), and (3ß)-22,23-epoxytirucall-7-ene-3,24,25-triol (19). In the 
Table 1. Compounds isolated from genus Munronia

\begin{tabular}{|c|c|c|c|}
\hline Type & Species & Compounds & References \\
\hline \multirow[t]{9}{*}{ Steroid } & \multirow[t]{2}{*}{ M. henryi } & sitosterol-3-O-12',13'-epoxy-9'-oxo-(10’E)-octadecenoate (1) & {$[57]$} \\
\hline & & $2 \beta, 3 \beta, 4 \beta$-trihydroxypregnan-16-one (2) & {$[57]$} \\
\hline & \multirow[t]{7}{*}{ M. delavayi } & $2 \alpha, 3 \alpha, 15 \beta$-trihydroxy-20(S)-tigloylpregnane (3) & [59] \\
\hline & & $\beta$-daucosterol (4) & [59] \\
\hline & & 6-hydroxystigmast-4-en-3-one (5) & [59] \\
\hline & & sitoindoside I (6) & {$[59]$} \\
\hline & & sitoindoside II (7) & [59] \\
\hline & & $\beta$-sitosterol (8) & {$[59]$} \\
\hline & & munronin S (9) & {$[50]$} \\
\hline \multirow[t]{7}{*}{ Terpenoid } & \multirow[t]{2}{*}{ M. henryi } & $4 \alpha, 7 \alpha$-aromadendranediol (10) & {$[51]$} \\
\hline & & munronin $\mathrm{R}(12)$ & {$[61]$} \\
\hline & \multirow{5}{*}{ M. delavayi } & geranylgeraniol (11) & {$[60]$} \\
\hline & & sapelin A (13) & {$[60]$} \\
\hline & & munronosides I-IV (14-17) & {$[60]$} \\
\hline & & melianodiol (18) & {$[60]$} \\
\hline & & (3ß)-22,23-epoxytirucall-7-ene-3,24,25-triol (19) & {$[60]$} \\
\hline \multirow[t]{21}{*}{ Limonoid } & \multirow[t]{12}{*}{ M. henryi } & munroniamide (20) & {$[51]$} \\
\hline & & munronins A-F (21-26) & {$[57]$} \\
\hline & & munronolide (27) & {$[65]$} \\
\hline & & munronolide $21-O-\beta$-D-glucopyranoside (28) & {$[65]$} \\
\hline & & munronins A-N (54-67) & {$[61]$} \\
\hline & & munronins $\mathrm{O}-\mathrm{Q}(\mathbf{6 8 - 7 0})$ & {$[70]$} \\
\hline & & chisonimbolinin $\mathrm{F}(\mathbf{7 1})$ & {$[70]$} \\
\hline & & 12-O-methylvolkensin (72) & {$[70]$} \\
\hline & & C-seco nimbolinin (73) & {$[70]$} \\
\hline & & prieurianin $(74)$ & {$[70]$} \\
\hline & & aphanamixoid F (75) & {$[70]$} \\
\hline & & $6 a$-hydroxy-14,15-deoxyhavanensin triacetate (76) & {$[70]$} \\
\hline & \multirow[t]{5}{*}{ M. delavayi } & munronin G (29) & {$[60]$} \\
\hline & & mulavanins A-E (30-34) & {$[66]$} \\
\hline & & mombasol (35) & {$[66]$} \\
\hline & & $14,15 \beta$-epoxyprieurianin (36) & {$[66]$} \\
\hline & & nymania $3(37)$ & {$[66]$} \\
\hline & M. sinica & 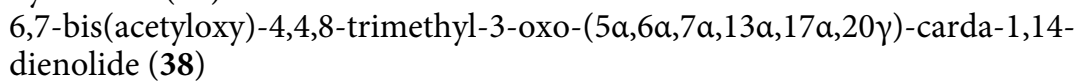 & {$[67]$} \\
\hline & \multirow[t]{2}{*}{ M. unifoliata } & munronoids A-J (39-48) & {$[68]$} \\
\hline & & munronoids K-O (49-53) & {$[69]$} \\
\hline & M. pinnata & munropins A-F (77-82) & [71] \\
\hline \multirow[t]{8}{*}{ Glycosides } & \multirow[t]{3}{*}{ M. henryi } & a-D-glucopyranosyl-6'-O-hexadecanoate (83) & {$[57]$} \\
\hline & & 4-O-a-D-psicofuranos- $\alpha$-D-glucopyranose $(\mathbf{8 4})$ & {$[57]$} \\
\hline & & glyceryl-1-tetracosanoicate (85) & {$[57]$} \\
\hline & \multirow[t]{5}{*}{ M. sinica } & musinins $A$ and $B(86$ and 87$)$ & {$[67]$} \\
\hline & & glucoacetosyringone (88) & {$[67]$} \\
\hline & & cannabiside D (89) & {$[67]$} \\
\hline & & corchoionoside C (90) & {$[67]$} \\
\hline & & (+)-3-oxo- $\alpha$-ionyl glucoside (91) & {$[67]$} \\
\hline \multirow[t]{3}{*}{ Flavonoid } & \multirow[t]{3}{*}{ M. delavayi } & kaempferol (92) & {$[59]$} \\
\hline & & quercetin $(93)$ & [59] \\
\hline & & rutin $(94)$ & [59] \\
\hline \multirow[t]{3}{*}{ Ceramides } & \multirow[t]{3}{*}{ M. henryi } & $\begin{array}{l}\text { 1-O- } \beta \text {-D-glucopyranosyl- }(2 S, 3 S, 4 R, 8 Z)-2-N \text {-(2'-hydroxytetracosanoyl)- } \\
\text { heptadecasphinga-8-ene (95) }\end{array}$ & [57] \\
\hline & & $(2 S, 3 S, 4 R, 8 E)-2-N-(2$ '-hydroxytetracosanoyl)-heptadecasphinga-8-ene (96) & {$[57]$} \\
\hline & & $(2 S, 3 R, 4 E)-2-N-(2$ '-hydroxytetracosanoyl)heptadecasphinga-4-ene (97) & [57] \\
\hline
\end{tabular}



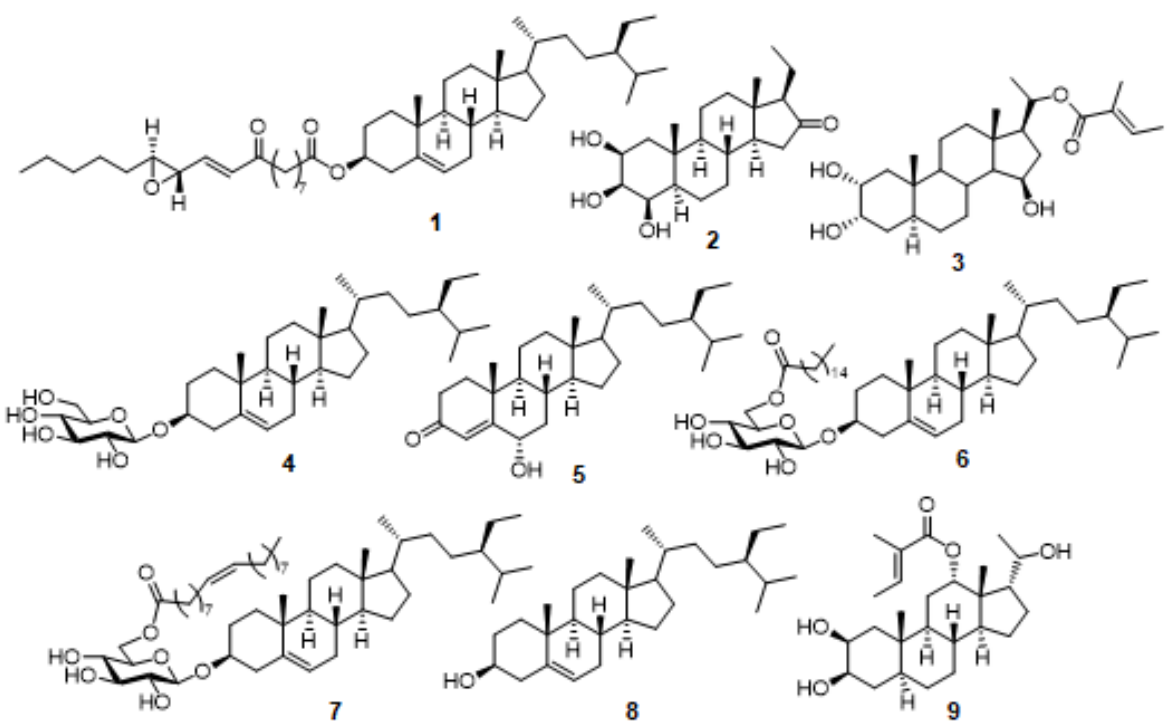

Fig 1. Steroid compounds isolated from genus Munronia (1-9)

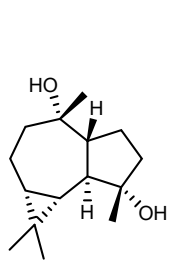

10
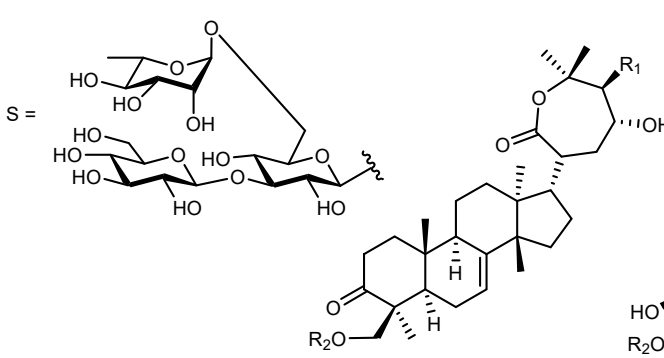

$14: R_{1}=O H, R_{2}=S$
$16: R_{1}=O A C, R_{2}=S$

$$
\mathrm{R}_{2} \mathrm{O}
$$

$15: \mathrm{R}_{1}=\mathrm{OH}, \mathrm{R}_{2}=\mathrm{S}$ $17: R_{1}=O A c, R_{2}=S$<smiles>CCOCCC1CCC2(C)C3CCC4(C)C(C)CCC(=O)C4(C)CCC3CC12C</smiles>

13<smiles>CC1(C)CCCC(O)[C@H]1O</smiles>

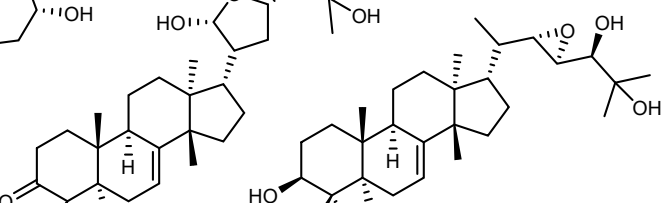<smiles>CC[C@@H]1C(CC/C(C)=C/C(=O)OC)=C(C)C(O)[C@@H]1O</smiles>

12 position of C-29, 14-17 attached to a trisaccharide moiety, which was, $O-\beta$-D-glucopyranosyl- $(1 \rightarrow 3)-O-[\alpha-\mathrm{L}$-rhamno pyranosyl-( $(1 \rightarrow 6)]-\beta$-D-glucopyranosyl. The chemical structures and source of terpenoid compounds reported in genus Munronia are shown in Fig, 2 and Table 1, respectively. 


\section{Limonoid}

Structurally, limonoids are defined as degraded triterpenoids with about four loose carbon atoms in the side chain position, and it is therefore called the tetranortriterpenoid [62]. These compounds are highly oxygenated and rearranged than triterpenoids, having such a broad structural diversity including additional hydroxyl, ketone, ester, ring-opening, and formation of furan or lactone groups in the side chain [63]. The Meliaceae family is known to be the source of a large number of limonoids including genus Munronia [64].

The first limonoid isolation, i.e. munroniamide (20) from $M$. henryi was reported by Qi and coworkers [51]. Compound 20 has an open ring at $A$ and $B$, carrying $\alpha, \beta$ unsaturated lactone moiety in the $\mathrm{A}$ ring and lactam unit in side chain. The further chemical investigation on this species gave six new limonoid compounds, i.e. munronins A-F (21-26). In compounds 23-26, the side chains were relatively rare in limonoid compounds, which is $\alpha, \beta-$ unsaturated lactone, $\alpha, \beta$-unsaturated lactam, and alkyne groups, respectively [57]. From the same species, Zhang et al. [65] obtained limonoid compound, munronolide
(27) and munronolide 21-O- $\beta$-D-glucopyranoside (28). Surprisingly, $\mathbf{2 8}$ were the first record compound with the glucose moiety attached to C-21 position. From $M$. delavayi, munronin $\mathrm{G}$ (29) has been obtained by Cai and Luo [60]. Munronin G (29) showed same skeleton with munronolide (27), with the major difference was the presence of a furan ring in the side chain. The chemical structures and source of 20-29 are shown in Fig. 3 and Table 1 , respectively.

The extensive isolation and identification of compounds from M. delavayi, Lin et al. [66] reported new limonoid compounds, mulavanins A-E (30-34) together with three known limonoids, i.e. mombasol (35), 14,15ß-epoxyprieurianin (36) and nymania 3 (37). It was reported that tigloyl unit appears to be attached on C-12 of 30-34. From M. sinica, Li et al. [67] obtained limonoid compound, 6,7-bis(acetyloxy)-4,4,8-trimethyl-

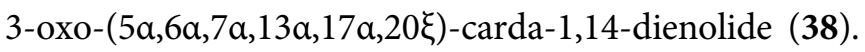
Species of $M$. unifoliata also produced many new limonoids with interesting diversity. Fifteen new limonoids were successfully isolated and characterized by Ge et al. [68-69] named, munronoids A-J (39-48) and
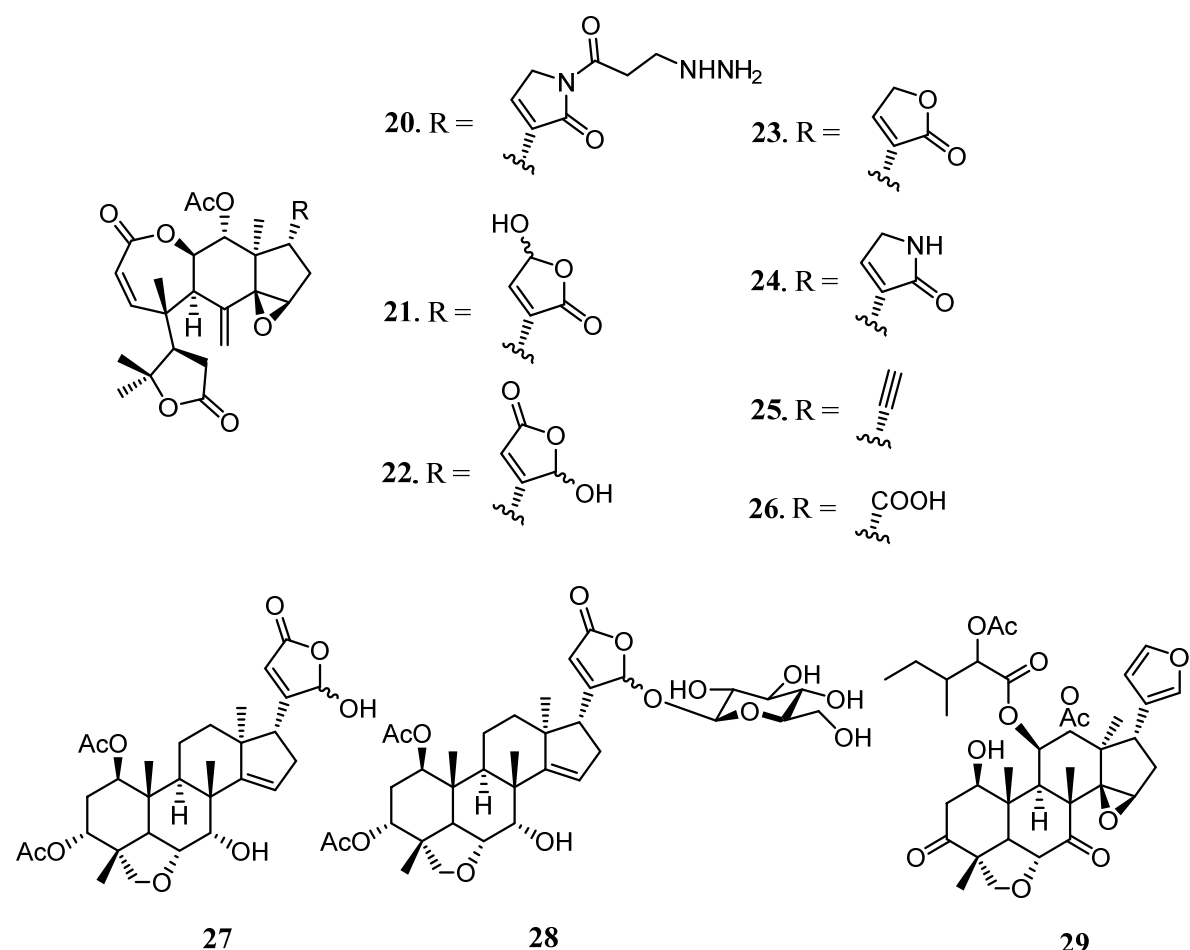

29

Fig 3. The chemical structure of 20-29 
munronoids K-O (49-53). These limonoids possessed skeleton of peieurianin, evodulone, euphane, and havanensin-types of limonoids. The structures and source of limonoid 30-53 is shown in Fig. 4 and Table 1, respectively.

Other limonoid compounds also isolated from this species, namely chisonimbolinin F (71), 12-O- methylvolkensin (72), C-seco nimbolinin (73), prieurianin (74), aphanamixoid $\mathrm{F}(75)$, and 6a-hydroxy14,15-deoxyhavanensin triacetate (76). Compound 54 represents the first limonoid reported with a novel 7oxabicyclo[2.2.1]-heptane moiety produced by incorporating C-11 and C-14 via an oxygen atom [70]. The latest phytochemistry investigation from M. pinnata,

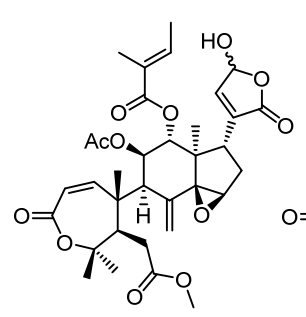

30

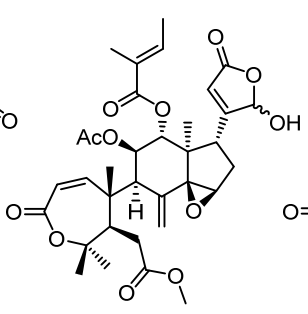

31

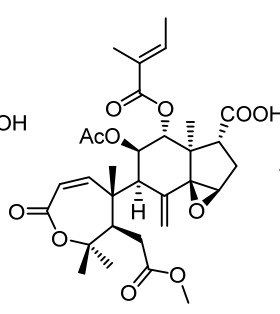

32

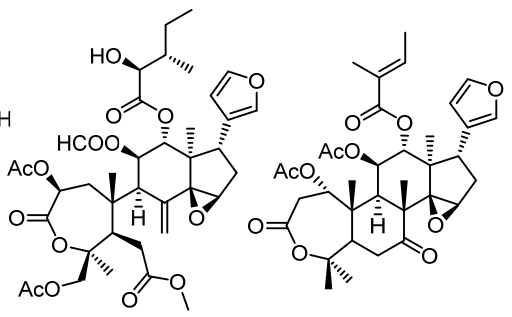

33

34

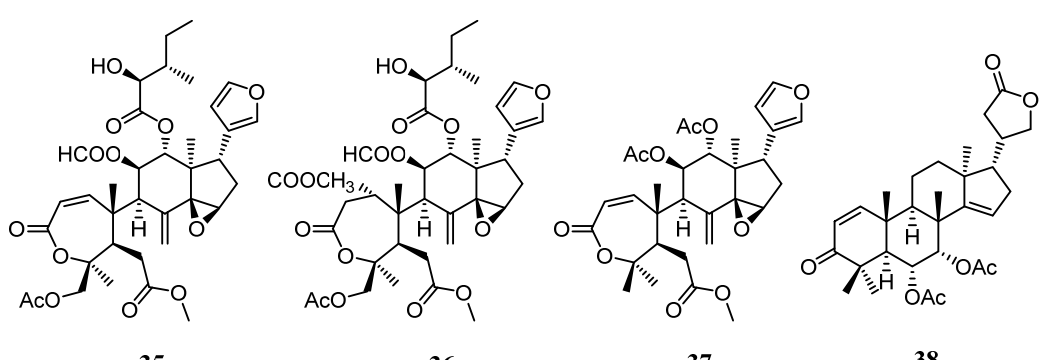

35

36

$37 \quad 38$

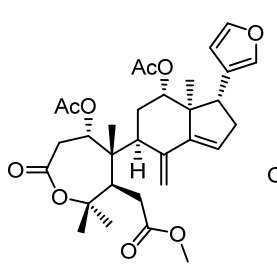

39

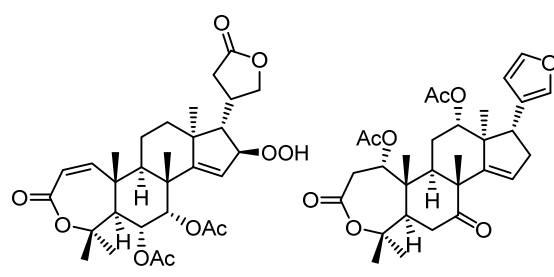

44

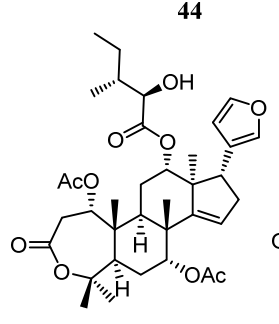

49

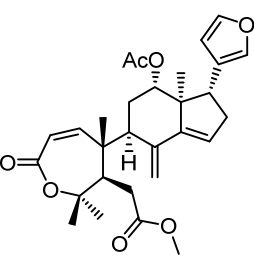

40

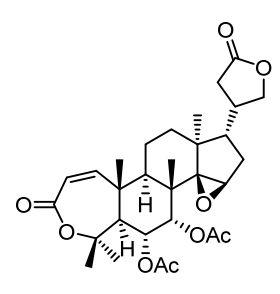

41

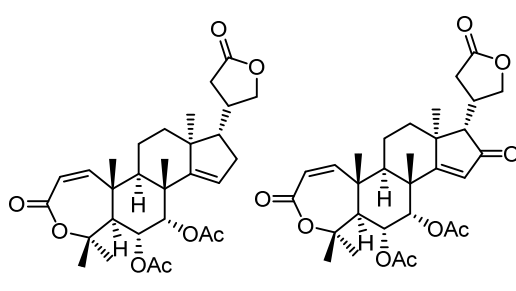

42

43

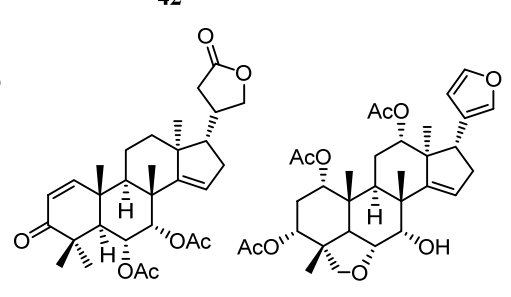

48

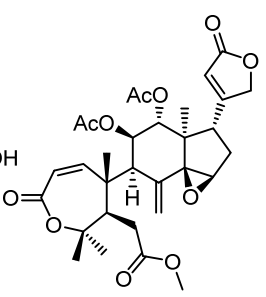

52

53

Fig 4. The chemical structure of 30-53 

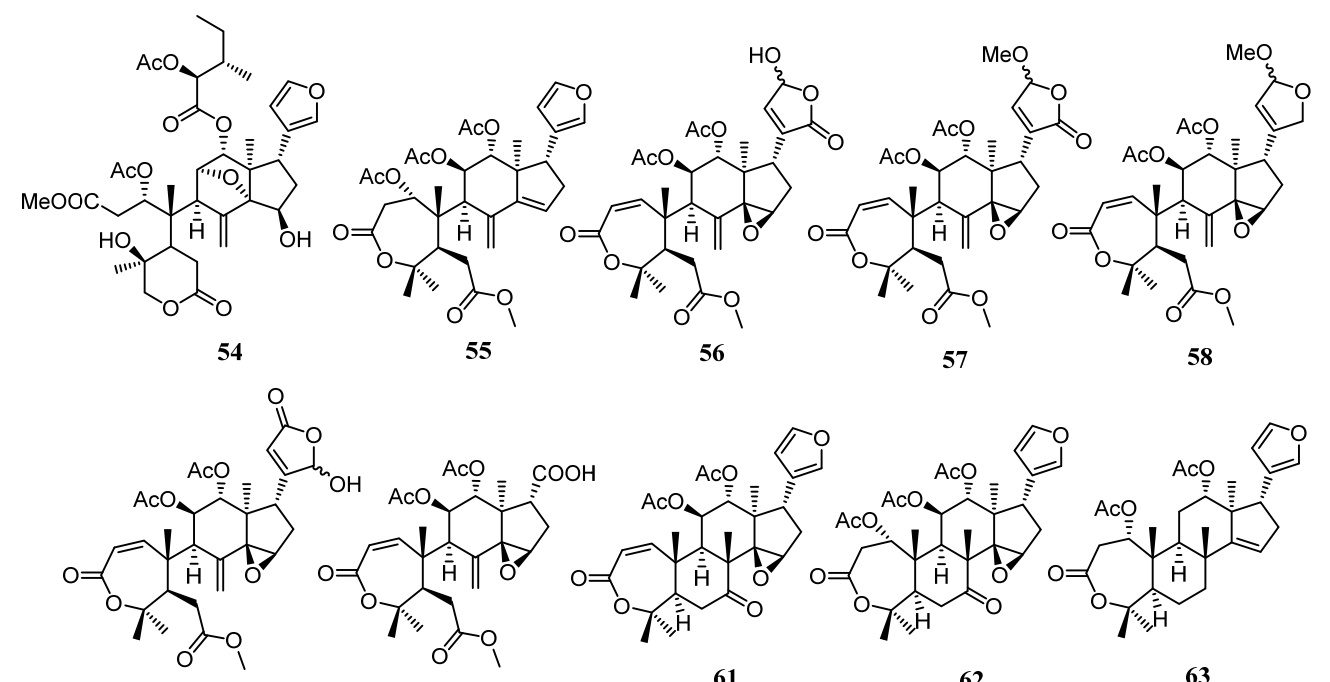

59

60

61

62

63
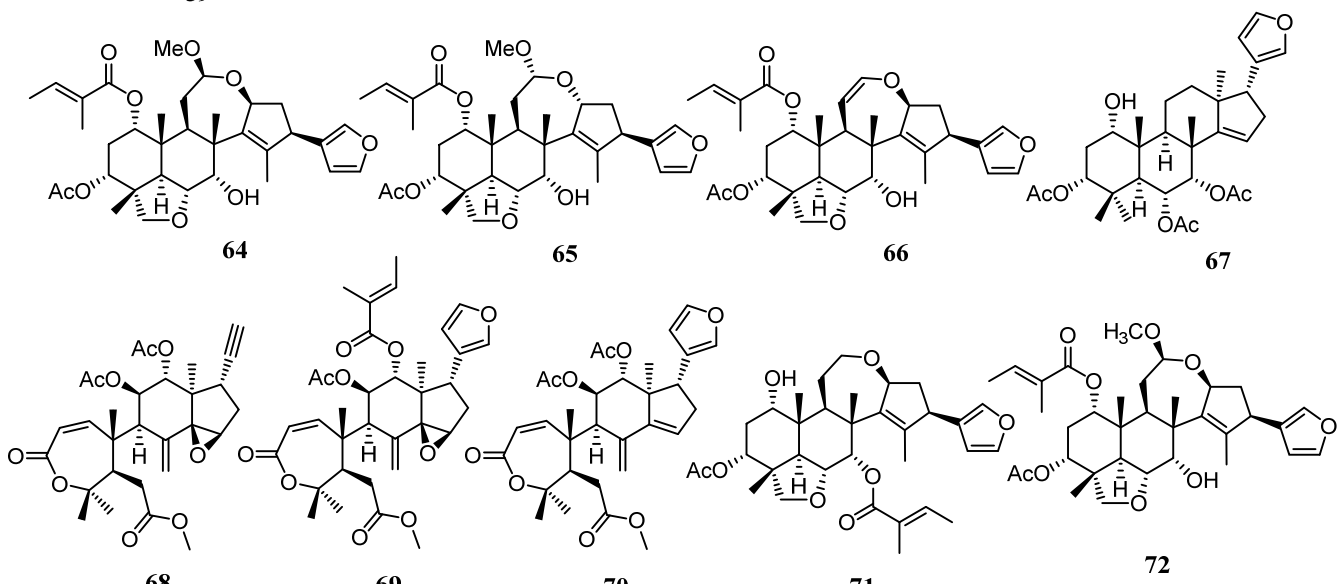

68

69

70
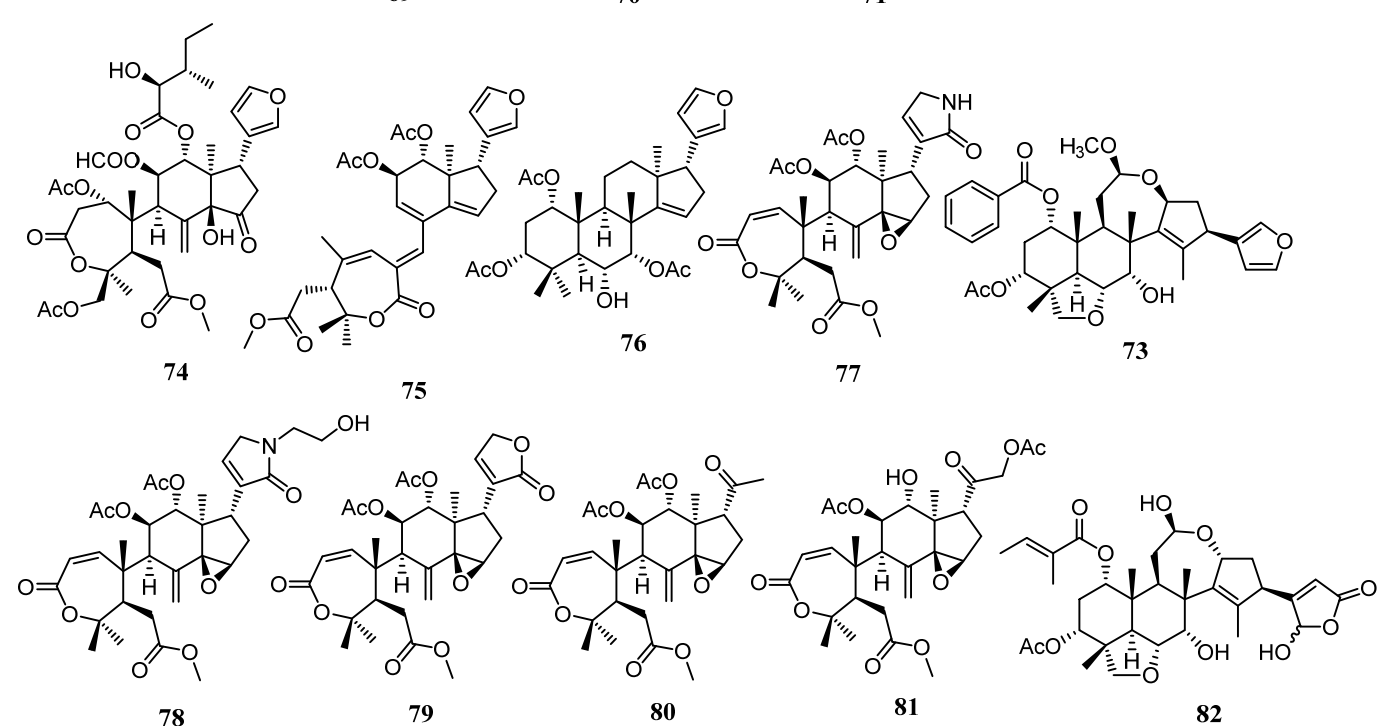

Fig 5. The chemical structure of 54-82

showed the presence of limonoids, munropins A-F (77- prieurianin skeleton with $\alpha, \beta$-unsaturated $\gamma$-lactam 82). Munropins A (77) and B (78) were classified as a moieties at C-17. Munropins C (79), D (80), and E (81) 
including prieurianin-type limonoids with an $\alpha, \beta$ unsaturated $\gamma$-lactone moiety, an acetyl group, and an acetoxyacetyl group at C-17, respectively. Munropin F (82) was assigned as a nimbolidin-type limonoid with a $\gamma$ hydroxy- $\alpha, \beta$-unsaturated $\gamma$-lactone moiety [71]. The chemical structures and source of limonoids 54-82 are shown in Fig. 5 and Table 1, respectively.

\section{Other compounds}

Glycosides, ceramides, and flavonoids were also found in several species of Munronia. M. henryi produced glycosides, $\alpha$-D-glucopyranosyl-6'-O-hexadecanoate (83), 4-O- $\alpha$-D-psicofuranos- $\alpha$-D-glucopyranose (84), and glyceryl-1-tetracosanoicate (85) [57]. Meanwhile, $M$. sinica contained other glycosides such as musinins A and B (86 and 87), glucoacetosyringone (88), cannabiside D (89), corchoionoside C (90), and (+)-3-oxo- $\alpha$-ionyl glucoside (91) [67]. Flavonoid compounds were obtained from $M$. delavayi, such as kaempferol (92), quercetin (93), and rutin (94) [59]. Qi et al. [57] showed the presence of three ceramides, $\quad 1-O-\beta$-D-glucopyranosyl-( $2 S, 3 S, 4 R, 8 Z)-2-$ $\mathrm{N}$-(2'-hydroxytetracosanoyl)-hepta-decasphinga-8-ene (95), (2S,3S,4R,8E)-2-N-(2'-hydroxytetracosanoyl)-hepta decasphinga-8-ene (96), and (2S,3R, 4E)-2-N-(2'-hydroxy tetracosan-oyl)heptadecasphinga-4-ene (97). The chemical structures and source of 83-97 are shown in Fig. 6 and Table 1, respectively.

\section{- BIOlOgICAL ACTIVITIES}

Plants of the genus Munronia have long been used in traditional medicine in various countries such as China, India, and Sri Lanka for treatment of dysentery, fever, malaria, skin disease, and purification of blood due to venomous snake bite [55] and to prevent hiccups, vomiting and sore throats [56]. Four species have been reported from this genus, and compounds have shown interesting biological activities such as insect antifeedant [51,57], antimicrobial [66], anti-tobacco mosaic virus [61,68-69], antiangiogenic [67], and cytotoxic activity [61].

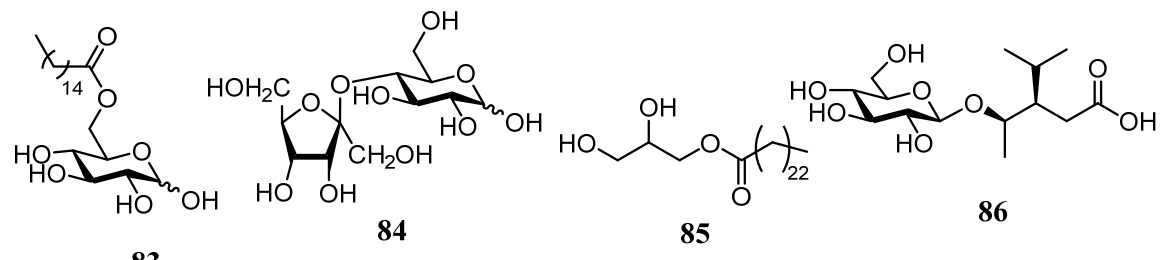

83<smiles>COc1cc(C(C)O)cc(OC)c1OC1OC(O)C2OC1C(O)C(O)C2O</smiles>

87

88

89

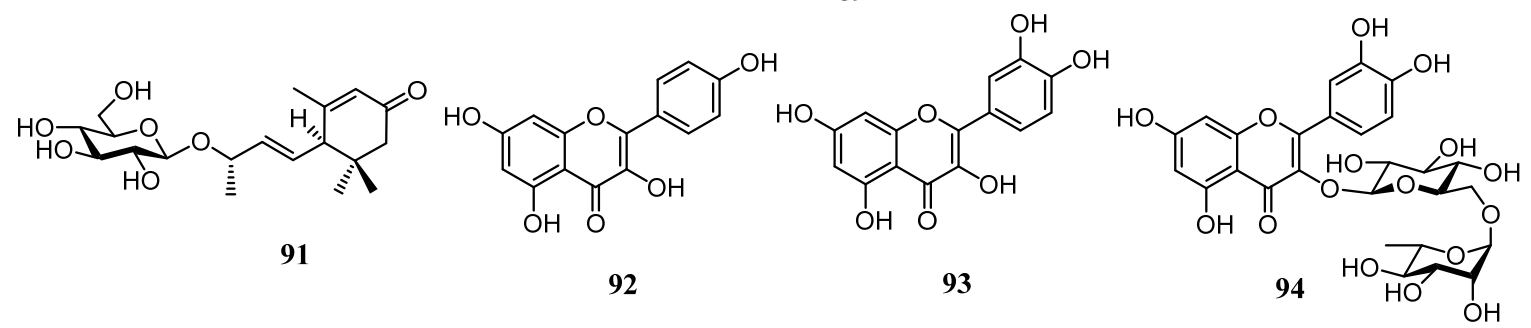

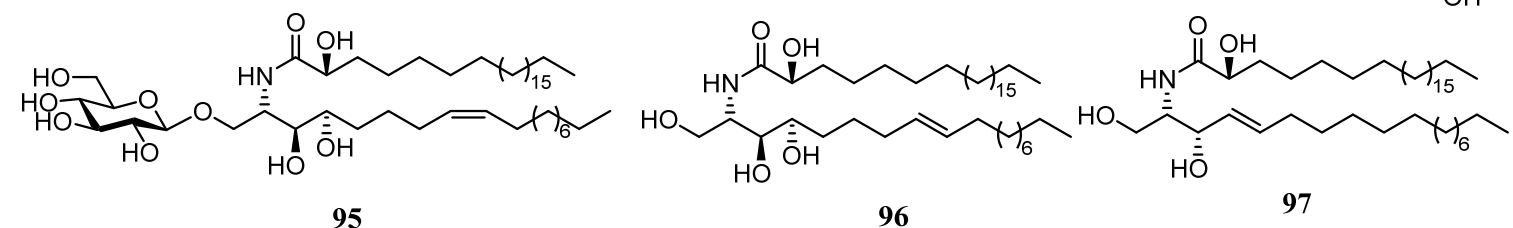

Fig 6. The chemical structure of 83-97 


\section{Insect Antifeedant Activity}

The first reported antifeedant activity of compounds isolated from the genus Munronia was reported from $M$. henryi. Qi et al. [72] reported that munroniamide (2) exhibited moderate activity, while ceramide 95 showed significant antifeedant activity. Meanwhile, ceramides 96 and 97 showed negative activity against Pieris brassicae L. For azadirachtin, munroniamide (2) showed only $10 \%$ mortality while $\mathbf{9 5}$ showed 50\% mortality (azadirachtin was $100 \%$ mortality). Furthermore, Qi et al. [51] also reported antifeedant activity of limonoids and munronins A-E (21-25) showed moderate activity with a mortality rate of about $10-20 \%$, meanwhile munronin $F$ (26) showed negative. Azadirachtin was used as a positive control in all the experiment. From species M. unifoliata, Ge et al. [68] reported that munronoid A (39) and munronoid D (42) showed moderate insecticidal activities, with lethal concentration $50\left(\mathrm{LC}_{50}\right)$ values at a concentration of $200 \mu \mathrm{g} / \mathrm{mL}$ and $23.3 \%$ (39), 53.3\% (42) against Brassica oleracea var. capitate.

\section{Antimicrobial Activity}

Li et al. [66] reported the isolation of limonoids and other constituents from $M$. delavayi for antimicrobial activity. The results showed that mulavanin $\mathrm{D}(33)$ and $2 \alpha, 3 \alpha, 15 \beta$-trihydroxy-20(S)-tigloyl-pregnane (3) showed modest activity against Microsporum gypseum and Trichophyton rubrum with minimum inhibitory concentration (MIC) values at 25 and $50 \mu \mathrm{g} / \mathrm{mL}$, respectively. In this test, amphotericin $\mathrm{B}$ was used as a positive control with a MIC of $1.56 \mu \mathrm{g} / \mathrm{mL}$ against both fungi.

\section{Antiangiongenic, Cytotoxic and Inducing Apoptosis Activity}

A limonoid compound reported in M. sinica, 38, has an inhibition ratio of about $58.7 \%$ at a concentration of 40 $\mu \mathrm{g} / \mathrm{mL}$. The results show that the intersegmental vessels of embryos treated with $\mathbf{3 8}$ were significantly less than that of the control PTK787. The cytotoxic activity of compounds isolated from $M$. sinica, limonoid 38 and glycosides 86-91, by Li et al. [67] also tested against A549 lung cancer cells using MTT assay. The results clearly showed that compounds $38,86,87$, and 91 exhibited a certain antiproliferative activity. Based on the acridine orange staining, compound $\mathbf{3 8}$ showed an obvious effect of inducing apoptosis of A549 lung cancer cells [67]. The in vitro cytotoxicity against human cancer HL-60, SMMC-7721, A-549, MCF-7, and SW-480 cell lines were investigated for limonoids, 54-76. The result showed that compounds $\mathbf{5 4}$ and $\mathbf{7 4}$ exhibited cytotoxic effects for all five cancer cell lines, with half-maximal inhibitory concentration $\left(\mathrm{IC}_{50}\right.$ ) values in the range of $0.4-4.8 \mu \mathrm{M}$ [61].

\section{Anti-tobacco Mosaic Virus Activity (Anti-TMV Activity)}

The limonoids isolated by Ge et al. [68] from $M$. unifoliata were tested for anti-TMV activity. Munronoid A (39) was screened according to the conventional halfleaf and leaf-disk method along with Western blot analysis, and showed strong anti-TMV activity, with an inhibition value at a concentration of $1 \mu \mathrm{g} / \mathrm{mL}$ was $50 \%$. Munronoid C (41), munronoid D (42), and munronoid F (44) were screened by the conventional halfleaf method along with Western blot analysis, and showed moderate antiviral activities, with inhibition values at a concentration of $500 \mu \mathrm{g} / \mathrm{mL}$ were $25.4 \%$ (41), $29.3 \%$ (42), and $37.2 \%$ (44), respectively. Further investigations on anti-TMV activity on limonoids obtained from $M$. unifoliata, munronoid K-O (49-53) were evaluated using half-leaf, enzyme-linked immunosorbent assay, and Western blot methods. Limonoids 49 and 53 showed stronger anti-TMV treatment activities than the positive control ningnanmycin. All compounds (49-55) showed inhibitory activities against TMV [69]. According to M. henryi, Yan et al. [61] evaluated the anti-TMV activity of limonoids, i.e. munronins A-N (54-67). Among these evaluated compounds, compounds 55, 61, 62, 63, 64, 65, and 74 showed significant anti-TMV activity, with $\mathrm{IC}_{50}$ values in the range $19.6-44.4 \mu \mathrm{g} / \mathrm{mL}$. The preliminary structureactivity relationships of these limonoids indicated that the presence of an $\alpha, \beta$-unsaturated lactone and an acetyl group located at C-7 are important for increasing the activity. Furthermore, munronins O-Q (68-70) which was also isolated from $M$. henryi, was tested for anti 
TMV activity. Among these, $\mathbf{7 0}$ exhibited the best activity, with an $\mathrm{IC}_{50}$ value of $14.8 \mu \mathrm{g} / \mathrm{mL}$, which was two-fold stronger than that of control ningnamycin $(44.6 \mu \mathrm{g} / \mathrm{mL})$.

\section{- CONCLUSION}

For 17 years, researchers have been interested in investigating the chemical composition of genus Munronia, a valuable medicinal plant in many countries, such as China, India, and Srilanka. About five species out of over 17 plants from genus Munronia has been extensively investigated. 97 compounds isolated from genus Munronia distributed into steroids, terpenoids, limonoids, and other metabolites. Various biological activities have been reported from these metabolites, including insect antifeedant, antimicrobial, antiangiongenic, cytotoxic, and inducing apoptosis, and anti-tobacco mosaic virus activity.

\section{- ACKNOWLEDGMENTS}

The authors are grateful to the Universitas Padjadjaran under the Post-Doctoral Grant, No: 3570/UN6.3.1/LT/2020, by Unang Supratman and Academic Leadership Grant, No: 1959/UN6.3.1/PT.00/ 2021 by Unang Supratman.

\section{- REFERENCES}

[1] Christenhusz, M.J.M., and Byng, J.W., 2016, The number of known plants species in the world and its annual increase, Phytotaxa, 261 (3), 201-217.

[2] Milawati, H., Harneti, D., Maharani, R., Nurlelasari, Hidayat, A.T., Azmi, M.N., Shiono, Y., and Supratman, U., 2019, Caryophyllen-type sesquiterpenoids from the stembark of Aglaia harmsiana and their cytotoxic activity against MCF7 breast cancer cells, Molekul, 14 (2), 126-132.

[3] Pan, L., Acuña, U.M., Li, J., Jena, N., Ninh, T.N., Pannel, C.M., Chai, H., Fuchs, J.R., Carcache de Blanco, E.J., Soejarto, D.D., and Kinghorn, D., 2013, Bioactive flavaglines and other constituents isolated from Aglaia perviridis, J. Nat. Prod., 76 (3), 394-404.

[4] Liu, S., Liu, S.B., Zuo, W., Guo, Z., Mei, W., and Dai, H., 2014, New sesquiterpenoids from Aglaia odorata var. Microphyllina and their cytotoxic activity, Fitoterapia, 92, 93-99.
[5] Kurniasih, N., Milawati, H., Fajar, M., Hidayat, A.T., Abdullah, R., Harneti, D., Supratman, U., and Azmi, M.N., 2018, Sesquiterpenoid compounds from the stembark of Aglaia minahassae (Meliaceae), Molekul, 13 (1), 56-62.

[6] Phongmaykin, J., Kumamoto, T., Ishikawa, T., Suttisri, R., and Saifah, E., 2008, A new sesquiterpene and other terpenoid constituents of Chisocheton penduliflorus, Arch. Pharmacal Res., 31 (1), 21-27.

[7] Yang, M.H., Wang, J.S., and Kong, L.Y., 2012, Chemical constituents of Chisocheton cumingianus, Chin. J. New Drugs, 21, 555-560.

[8] Awang, K., Loong, X.M., Leong, K.H., Supratman, U., Litaudon, M., Mukhtar, M.R., and Mohamad, K., 2012, Triterpenes and steroids from the leaves of Aglaia exima (Meliaceae), Fitoterapia, 83 (8), 13911395.

[9] Yodsaoue, O., Sonprasit, J., Karalai, C., Ponglimanont, C., Tewtrakul, S., and Chantrapromma, S., 2012, Diterpenoids and triterpenoids with potential antiinflammatory activity from the leaves of Aglaia odorata, Phytochemistry, 76, 83-91.

[10] Zhang, H., Xu, H.H., Song, Z.J., Chen, L.Y., and Wen, H.J., 2012, Molluscidal activity of Aglaia duperreana and the constituents of its twigs and leaves, Fitoterapia, 83 (6), 1081-1086.

[11] Harneti, ～D., Tjokronegoro, R., Safari, A., Supratman, U., Loong, X.M., Mukhtar, M.R., Mohamad, K., Awang, K., and Hayashi, H., 2012, Cytotoxic triterpenoids from the bark of Aglaia smithii (Meliaceae), Phytochem. Lett., 5 (3), 496-499.

[12] Harneti, D., Supriadin, S., Ulfah, M., Safari, A., Supratman, U., Awang, K., and Hayashi, H., 2014, Cytotoxic constituents from the bark of Aglaia eximia (Meliaceae), Phytochem. Lett., 8, 28-31.

[13] Hidayat, A.T., Farabi, K., Harneti, H., Nurlelasari, Maharani, R., Nurfarida, I., Supratman, U., and Shiono, Y., 2018, Cytotoxic triterpenoids from the stembark of Aglaia argentea (Meliaceae), Indones. J. Chem., 18 (1), 35-42.

[14] Zhang, F., He, X.F., Wu, W.B., Chen, W.S., and Yue, J.M., 2012, New apotirucallane-type triterpenoids 
from Chisocheton paniculatus, Nat. Prod. Bioprospect., 2 (6), 235-239.

[15] Yang, M.H., Wang, J.S., Luo, J.G., Wang, X.B., and Kong, L.Y., 2012, Four new triterpenoids from Chisocheton paniculatus and their anti-inflammatory activities, Can. J. Chem., 90 (2), 199-204.

[16] Yang, M.H., Wang, J.S., Luo, J.G., Wang, X.B., and Kong, L.Y., 2012, Tetranortriterpenoids from Chisocheton paniculatus, J. Nat. Prod., 75 (2), 308.

[17] Chan, K.Y., Mohamad, K., Ooi, A.J.A., Imiyabir, Z., and Chung, L.Y., 2012, Bioactivity-guided fractionation of the lipoxygenase and cyclooxygenase inhibiting constituents from Chisocheton polyandrus Merr, Fitoterapia, 83 (5), 961-967.

[18] Najmuldeen, I.A., Hadi, A.H.A., Mohamad, K., Awang, K., Nasab, M.F., Ketuly, K.A., Mukhtar, M.R., and Morita, H., 2011, Steroids from Chisocheton tomentosus, Malays. J. Sci., 30 (2), 144-153.

[19] Liu, J., He, X.F., Wang, G.H., Merino, E.F., Yang, S.P., Zhu, R.X., Gan, L.S., Zhang, H., Cassera, M.B., Wang, H.Y., Kingston, D.G.I., and Yue, J.M., 2014, Aphadilactones A-D, four diterpenoid dimers with DGAT inhibitory and antimalarial activities from a Meliaceae plant, J. Org. Chem., 79 (2), 599-607.

[20] Zhang, W.M., Liu, J.Q., Deng, Y.Y., Xia, J.J., Zhang, Z.R., Li, Z.R., and Qiu, M.H., 2014, Diterpenoids and limonoids from the leaves and twigs of Swietenia mahagoni, Nat. Prod. Bioprospect., 4 (1), 53-57.

[21] Zhang, X., Tan, Y., Li, Y., Jin, L., Wei, N., Wu, H., Ma, G., Zheng, Q., Tian, Y., Yang, J., Zhang, J., and Xu, X., 2014, Aphanamixins A-F, acyclic diterpenoids from the stem bark of Aphanamixis polystachya, Chem. Pharm. Bull., 62 (5), 494-498.

[22] Farabi, K., Harneti, D., Nurlelasari, Maharani, R., Hidayat, A.C., Supratman, U., Awang, K., and Shiono, Y., 2017, Cytotoxic steroids from the bark of Aglaia argentea (Meliaceae), CMU J. Nat. Sci., 16 (4), 293-306.

[23] Farabi, K., Harneti, D., Nurlelasari, Maharani, R., Hidayat, A.C., Awang, K., Supratman, U., and Shiono, Y., 2018, New cytotoxic pregnane-type steroid from the stem bark of Aglaia elliptica (Meliaceae), Rec. Nat. Prod., 12 (2), 121-127.
[24] Hutagaol, R.P., Harneti, D., Hidayat, A.T., Nurlelasari, Maharani, R., Katja, D.G., Supratman, U., Awang, K., and Shiono, Y., 2020, (22E,24S)-24Propylcholest-5en-3a-acetate: A new steroid from the bark Aglaia angustifolia (Miq.) (Meliaceae), Molbank, 2020 (1), M1112.

[25] Awang, K., Loong, X.M., Leong, K.H., Supratman, U., Litaudon, M., Mukhtar, M.P., and Mohamad, K., 2012, Triterepenes and steroids from the leaves of Aglaia exima (Meliaceae), Fitoterapia, 83 (8), 1391-1395.

[26] Farabi, K., Harneti, D., Nurlelasari, Maharani, R., Hidayat, A.C., Awang, K., Supratman, U., and Shiono, Y., 2017, New cytotoxic protolimonoids from the stem bark of Aglaia argentea (Meliaceae), Phytochem. Lett., 21, 211-215.

[27] Fang, X., Di, Y.T., and Hao, X.J., 2011, The advances in the limonoid chemistry of the Meliaceae family, Curr. Org. Chem., 15 (9), 1363-1391.

[28] Sianturi, J., Purnamasari, M., Darwati, Harneti, D., Mayanti, D., Supratman, U., Awang, K., and Hayashi, H., 2015, New bisamide compounds from the bark of Aglaia eximia (Meliaceae), Phytochem. Lett., 13, 297-301.

[29] Duong, T.N., Edrada, R.A., Ebel, R., Wray, V., Frank, W., Duong, A.T., Lin, W.H., and Proksch, P., 2007, Putrescine bisamides from Aglaia gigantea, $J$. Nat. Prod., 70 (10), 1640-1643.

[30] Sianturi, J., Harneti, D., Darwati, Mayanti, T., Supratman, U., and Awang, K., 2016, A new (-)5,6-dimethoxyisolariciresinol-(3",4"'-dimethoxy)3a-O- $\beta$-D-glucopyranosides from the bark of Aglaia eximia (Meliaceae), Nat. Prod. Res., 30 (19), 22042208.

[31] Hidayat, A.T., Nurlelasari, N., Abdullah, F.F., Harneti, D., Maharani, R., Haikal, K., Supratman, U., and Azmi, M.N.A., 2018, New lignan derivative, lasiocarpone, from the stembark of Chisocheton lasiocarpus (Meliaceae), Orient. J. Chem., 34 (4), 1956-1960.

[32] Peng, L., Fu, W.X., Zeng, C.X., Zhou, L., Bao, M.F., and Cai, X.H., 2016, Two new lignans from twigs of 
Aglaia odorata, J. Asian Nat. Prod. Res., 18 (2), 147152.

[33] Joycharat, N., Greger, H., Hofer, O., and Saifah, E., 2008, Flavaglines and triterpenoids from the leaves of Aglaia forbesii, Phytochemistry, 69 (1), 206-211.

[34] Pan, L., Woodard, J.L., Lucas, D.M., Fuchs, J.R., and Kinghorn, A.D., 2014, Rocaglamide, silvestrol and structurally related bioactive compounds from Aglaia species, Nat. Prod. Rep., 31 (7), 924-939.

[35] An, F.L., Wang, X.B., Wang, H., Li, Z.R., Yang, M.H., Luo, J., and Kong, L.Y., 2016, Cytotoxic rocaglate derivatives from leaves of Aglaia perviridis, Sci. Rep., 6, 20045.

[36] Sianturi, J., Purnamasari, M., Mayanti, T., Harneti, D., Supratman, U., Awang, K., and Hayashi, H., 2015, Flavonoid compounds from the bark of Aglaia eximia (Meliaceae), Makara J. Sci., 19 (1), 7-12.

[37] Sianturi, J., Farabi, K., Mayanti, T., Harneti, D., Darwati, Supratman, U., Awang, K., and Hayashi, H., 2016, Antioxidant constituents from the bark of Aglaia eximia (Meliaceae), Makara J. Sci., 20 (1), 1-6.

[38] Salim, A.A., Chai, H.B., Rachman, I., Riswan, S., Kardono, L.B.S., Farnsworth, N.R., Carcache-Blanco, E.J., and Kinghorn, A.D., 2007, Constituents of the leaves and stem bark of Aglaia foveolata, Tetrahedron, 63 (33), 7926-7934.

[39] Kim, S., Chin, Y.W., Su, B.N., Riswan, S., Kardono, L.B.S., Afriastini, J.J., Chai, H., Farnsworth, N.R., Cordell, G.A., Swanson, S.M., and Kinghorn, A.D., 2006, Cytotoxic flavaglines and bisamides from Aglaia edulis, J. Nat. Prod., 69 (12), 1769-1775.

[40] Wu, T.S., Liou, M.J., Kuoh, C.S., Teng, C.M., Nagao, T., and Lee, K.H., 1997, Cytotoxic and antiplatelet aggregation priciples from Aglaia elliptifolia, J. Nat. Prod., 60 (6), 606-608.

[41] Mohamad, K., Sévenet, T., Dumontet, V., Paï, M., Tri, M.V., Hadi, H., Awang, K., and Martin, M.T., 1999, Dammarane triterpenes and pregnane steroids from Aglaia lawii and A. tomentosa, Phytochemistry, 51 (8), 1031-1037.

[42] Dreyer, M., Nugroho, B.W., Bohnenstengel, F.I., Ebel, R., Wray, V., Witte, L., Bringmann, G., Mühlbacher, J., Herold, M., Hung, D., Kiet, C., and
Proksch, P., 2001, New insecticidal rocaglamide derivatives and related compounds from Aglaia oligophylla, J. Nat. Prod., 64 (4), 415-420.

[43] Greger, H., Pacher, T., Brem, B., Bacher, M., and Hofer, O., 2001, Insecticidal flavaglines and other compounds from Fijian Aglaia species, Phytochemistry, 57 (1), 57-64.

[44] Fuzzati, N., Dyatmiko, W., Rahman, A., Achmad, F., and Hostettmann, K., 1996, Triterpenoids, lignans and a benzofuran derivative from the bark of Aglaia elaeagnoidea, Phytochemistry, 42 (5), 1395-1398.

[45] Engelmeier, D., Hadacek, F., Pacher, T., Vajrodaya, S., and Greger, H., 2000, Cyclopenta[b]benzofurans from Aglaia species with pronounced antifungal activity against rice blast fungus (Pyricularia grisea), J. Agric. Food Chem., 48 (4), 1400-1404.

[46] Chin, Y.W., Chae, H.S., Lee, J.K., Bach, T.T., Ahn, K.S., Lee, H.K., Joung, H., and Oh, S.R., 2010, Bisamides from the twigs of Aglaia perviridis collected in Vietnam, Bull. Korean Chem. Soc., 31 (9), 2665-2667.

[47] Yadav, R.D., Kataky, J.C.S., and Mathur, R.K., 1999, New protolimonoids and limonoids: Part IIsolation, structure elucidation of new protolimonoids and limonoid from the root wood of Chisocheton paniculatus Hiern (Meliaceae), Indian J. Chem., Sect. B, 38, 1359-1363.

[48] Saifah, E., Suttisri, R., Shamsub, S., Pengsuparp, T., and Lipipun, V., 1999, Bisamides from Aglaia edulis, Phytochemistry, 52 (6), 1085-1088.

[49] Zhang, R.J., Chen, H.F., Xing, F.W., and Ye, Y.S., 2009, Munronia yinggelingensis sp. nov. (Meliaceae) from Hainan, China, Nord. J. Bot., 27 (5), 376-378.

[50] Chen, P.Y., 1997, "Meliaceae" in Angiospermae: Dicotyledoneae, Simaroubaceae, Burseraceae, Meliaceae, Malpighiaceae, Polygalaceae, Dichapetalaceae, Eds. Chen, S.K., Science Press, Beijing, China, 34-104.

[51] Qi, S.H., Chen, L., Wu, D.G., Maa, W.B., and Luo, X.D., 2003, Novel tetranortriterpenoid derivatives from Munronia henryi, Tetrahedron, 59 (23), 41934199 . 
[52] Jia, J., Wu, H., Wang, J.F., and Gong, J.F.X., 2014, Genetic diversity and structure of Munronia delavayi Franch. (Meliaceae), an endemic species in the dryhot valley of Jinsha River, south-western China, Genet. Resour. Crop Evol., 61 (7), 1381-1395.

[53] Dassanayake, M.D., Fosberg, F.R., and Clayton, W.D., 1995, A Revised Handbook to the Flora of Ceylon, Vol. 9, Amerind Publishing Co. Pvt. Ltd., New Delhi, India.

[54] Dharmadasa, R.M., Hettiarachchi, P.L., and Premakumara, G.A.S., 2011, Geographical distribution and conservation of a rare medicinal plant Munronia pinnata (Wall.) Theob. (Meliaceae) in Sri Lanka, Bangladesh J. Plant Taxon., 18 (1), 39-49.

[55] Jayaweera, D.M.A., 1982, Medicinal Plants (Indigenous and Exotic) Used in Ceylon, Part 4, National Science Council of Sri Lanka, Colombo, Sri Lanka.

[56] Arambewela, L., and Wijesinghe, A., 2006, Sri Lankan Medicinal Plant Monographs and Analysis Vol. 12 Munronia pumila, National Science Foundation, Colombo, Sri Lanka.

[57] Qi, S.H., Wu, D.G., Ma, Y.B., and Luo, X.D., 2003, The chemical constituents of Munronia henryi, J. Asian Nat. Prod. Res., 5 (3), 215-221.

[58] Pennington, T.D., and Styles, B.T., 1975, A generic monograph of the Meliaceae, Blumea, 22 (3), 419-540.

[59] Cai, X.H., Luo, X.D., Zhou, J., and Hao, X.J., 2006, A new pregnane from Munronia delavayi Franch (Meliaceae), J. Integr. Plant Biol., 48 (9), 1126-1128.

[60] Cai, X.H., Du, Z.Z., and Luo, X.D., 2007, Tirucallane triterpenoid saponins from Munronia delavayi Franch, Helv. Chim. Acta, 90 (10), 1980-1986.

[61] Yan, Y., Yuan, C.M., Di, Y.T., Huang, T., Fan, Y.M., Ma, Y., Zhang, J.X., and Hao, X.J., 2015, Limonoids from Munronia henryi and their anti-tobacco mosaic virus activity, Fitoterapia, 107, 29-35.

[62] Zhang, Y., and Xu, H., 2017, Recent progress in the chemistry and biology of limonoids, RSC Adv., 7 (56), 35191-35220.
[63] Roy, A., and Saraf, S., 2006, Limonoids: Overview of significant bioactive triterpenes distributed in plants kingdom, Biol. Pharm. Bull., 29 (2), 191-201.

[64] Taylor, D.A.H., 1984, "The Chemistry of the Limonoids from Meliaceae" in 'Fortschritte der Chemie organischer Naturstoffe/Progress in the Chemistry of Organic Natural Products", vol. 45, Springer, Vienna, Austria.

[65] Zhang, H.P., Bao, G.H., Wang, H.B., and Qin, G.W., 2004, Two new limonoids from Munronia henryi, Nat. Prod. Res., 18 (5), 415-419.

[66] Lin, B.D., Chen, H.D., Liu, J., Zhang, S., Wu, Y., Dong, L., and Yue, J.M., 2010, Mulavanins A-E: Limonoids from Munronia delavayi, Phytochemistry, 71 (13), 1596-1601.

[67] Li, X.L., He, Q.X., Zhang, F.L., Zhao, Y.L., Liu, K.C., and Jiang, S.P., 2012, Chemical constituents from Munronia sinica and their bioactivities, Nat. Prod. Bioprospect., 2 (2), 76-80.

[68] Ge, Y.H., Zhang, J.X., Mu, S.Z., Chen, Y., Yang, F.M., Lü, Y., and Hao, X.J., 2012, Munronoids A-J, ten new limonoids from Munronia unifoliolata Oliv, Tetrahedron, 68 (2), 566-572.

[69] Ge, Y.H., Liu, K.X., Zhang, J.X., Mu, S.Z., and Hao, X.J., 2012, The limonoids and their anti-tobacco mosaic virus (TMV) activities from Munronia unifoliolata Oliv, J. Agric. Food Chem., 60 (17), 4289-4295.

[70] Yan, Y., Zhang, J.X., Huang, T., Mao, X.Y., Gu, W., He, H.P., Di, Y.T., Li, S.L., Chen, D.Z., Zhang, Y., and Hao, X.J., 2015, Bioactive limonoid constituents of Munronia henryi, J. Nat. Prod., 78 (4), 811-821.

[71] Yang, X.R., Tanaka, N., Tsuji, D., Lu, F.L., Yan, X.J., Itoh, K., Li, D.P., and Kashiwada, Y., 2019, Limonoids from the aerial parts of Munronia pinnata, Tetrahedron, 75 (52), 130779.

[72] Qi, S.H., Wu, D.G., Chen, L., Ma, Y.B., and Luo, X.D., 2003, Insect antifeedants from Munronia henryi: Structure of Munroniamide, J. Agric. Food Chem., 51 (24), 6949-6952. 